\title{
Robust coordinated control using backstepping of flywheel energy storage system and DFIG for power smoothing in wind power plants
}

\author{
Mohamed Nadour ${ }^{1}$, Ahmed Essadki ${ }^{2}$, Tamou Nasser ${ }^{3}$, Mohammed Fdaili ${ }^{4}$ \\ 1,2,4 Research Center of Engineering and Health Sciences and Technologies (STIS), High Normal School Of Technical \\ Eductaion, Mohammed V University, Morocco \\ ${ }^{3}$ Research Center of Engineering and Health Sciences and Technologies (STIS), Higher National School of Computer \\ Science and Systems Analysis, Mohammed V University, Morocco
}

\begin{tabular}{l} 
Article Info \\
\hline Article history: \\
Received Jan 2, 2019 \\
Revised Mar 1, 2019 \\
Accepted Mar 19, 2019 \\
\hline Keywords: \\
Backstepping Control \\
DFIG \\
Flywheel Energy Storage \\
Power smoothing \\
Wind Energy
\end{tabular}

Article Info

icle history:

Revised Mar 1, 2019

Keywords:

Backstepping Control

DFIG

Power smoothing

(n)

\begin{abstract}
This paper presents a robust coordinated control of a flywheel energy storage system FESS and a doubly-fed induction generator DFIG based wind turbine used to smooth the wind-induced output power fluctuations. The overall system control combines field and voltage oriented control schemes and nonlinear backstepping approach applied first, to the DFIG side converter DSC to regulate the stator active power in order to extract the maximum power from the wind velocity, and reactive power in order to maintain, at the point of common coupling PCC, a unity power factor. Then, to the electrical network side converter NSC to regulate DC bus voltage. Finally, to the flywheel side converter FSC allowing the storage unit to serve as a buffer that stores energy in the case of excess power and retrieves it back into the output in the case of power deficiency. Numerical simulations using Matlab/Simulink software demonstrate the validity of the proposed control strategies in terms of dynamic response, improvement of output power quality and robustness against model parametric variation.
\end{abstract}

Copyright (c) 2019 Institute of Advanced Engineering and Science. All rights reserved.

\section{Corresponding Author:}

Mohamed Nadour,

Research Center for Engineering and Health Sciences and Technologies, High Normal School of Technical Education, Mohammed V University, Enset, B.P. ،6207 Avenue des Forces Armées Royales, Rabat 10100, Morocco.

Email: mohamed.nadour@um5s.net.ma

\section{INTRODUCTION}

Environmental awareness, unstoppable rise of energy consumption along with late developments in the field of electrical and power electronics engineering are the main reasons why the world is now heading toward green, abundant and constantly replenished energy sources. Among a variety of these renewable sources, wind power has arise as one of the most economical and viable options for clean electricity generation. As this type of power generation continues flourishing worldwide, and as we keep on increasing its penetration level, the power system operator will inevitably confront some serious stability challenges. Being that the stochastic and fluctuating nature of the wind profile that is amplified in the output power (reaching about hundreds of $\mathrm{kW}$ in seconds) induces, in case of high wind power penetration or an isolated power system, frequency fluctuations as well as voltages fast (flickers) variations. That could considerably affect the electrical network operation and stability [1]. Therefore, the WECS must quickly take part in the ancillary services rather than only being considered as passive charges from the power system viewpoint [2].

Various configurations have been reccomended in order to reduce output power variation. A practical solution consists on allocating a short-term energy storage device such as superconducting magnetic energy storage (SMES) [3], supercapacitors [4] or flywheel energy storage system (FESS) [5], as an 
additional reserve that stores the energy in the case of excess power and retrieves it in the case of deficiency. Reference [6], presents a comparative study and a thorough full overview of the technical and economic performance on the available energy storage technologies. For instance, with their high efficiency, both high power and energy densities, and longer cycling life, the FESSs offer a very competitive option over the alternatives [7].

Among many other relevant works, in [2] a FESS is associated with a permanent magnet synchronous machine (PMSM) based wind power plant in order to smooth and improve the output power quality. Classical PI control laws along with a fuzzy logic supervisor are used for the power flow management between the FESS and the electrical grid while considering the storage device state of charge (SoC). Few have been the studies that suggested a profitable application of FESS to a DFIGURE The author in [8] has presented a solution that consists on connecting the FESS to the DC bus through an AC/DC converter in order to study the effects of reactive and active power quality improvement on load voltages using PI controllers. However, traditional control schemes do not always provide pleasing results, since they only guarantee the appropriate tracking response at a certain operating point for which the control law was already designed. Whereas, when a parametric variation is registered, which is usually the case due especially to modelling uncertainties and some physical phenomena, the performance of PI-based control scheme risk to be insurable and gravely deteriorated.

Accordingly, in attempt to meet higher performances, this paper presents a coordinated robust control of a FESS associated to a DFIG-based wind turbine using a systematic and recursive methodology used for nonlinear systems control known as backstepping (BS) [9]. Owing to this technique, the feedback control law that guarantees the system overall behavior and stability can be efficiently elaborated. Figure 1 shows the basic configuration of the system, where the stator windings of the DFIG are straightforwardly linked to the grid, while its rotor windings are linked via a back-to-back converter. The DFIG side converter DSC is used to control the generated reactive and active powers following a maximum power point tracking (MPPT) algorithm. The electrical network side converter NSC is used to keep constant the DC bus voltage regardless of the direction and magnitude of the power. Finally, the flywheel side converter FSC is controlled in order to smooth the wind-induced fluctuations and to improve the quality of the output active power. Simulation results performed in Matlab/Simulink verify the performance of the proposed control schemes, in terms of output power smoothing, dynamic response and robustness against parametric variation.

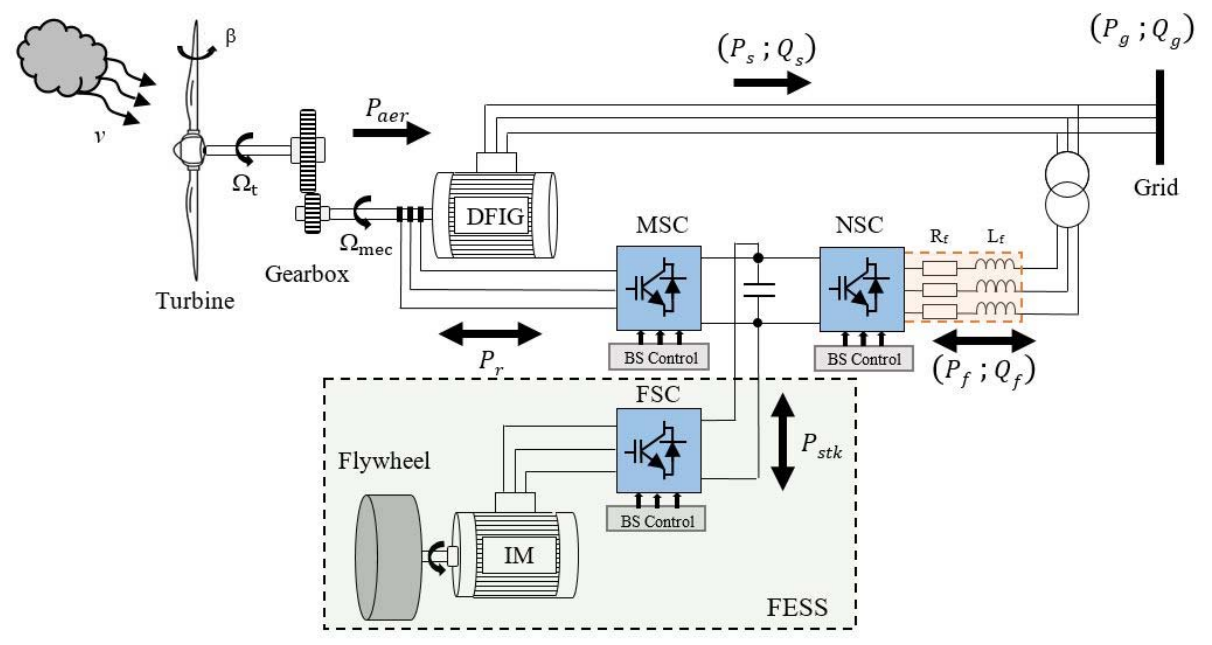

Figure 1. Studied system

The rest of the paper is arranged as follows: Section 2 presents the modelling of the wind turbine, the DFIG and the FESS. The proposed control strategies of the MSC, the GSC, and the FSC are discussed in details in Section 2. Simulation and interpretation of the results in Section 3. Finally, a conclusion in Section 4. 


\section{DYNAMIC MODELLING OF THE STUDIED SYSTEM}

\subsection{Wind turbine model}

The aerodynamic power harvested by the wind turbine $\mathrm{P}_{\mathrm{h}}$ can be expressed as function of the power coefficient $\mathrm{C}_{\mathrm{p}}$ as follows [10-12]:

$$
\mathrm{P}_{\mathrm{h}}=\mathrm{C}_{\mathrm{p}}(\lambda, \beta) \cdot \mathrm{P}_{\text {wind }}=0.5 \cdot \mathrm{C}_{\mathrm{p}}(\lambda, \beta) \cdot \rho A v^{3}, \lambda=\mathrm{R} \cdot \Omega_{\mathrm{T}} / \mathrm{v}
$$

Where $\mathrm{v}$ is the wind speed, $\rho$ is the air density and A represents the swept area, $\mathrm{R}$ is the blades radius and $\Omega_{T}$ is the turbine rotational speed. The coefficient $C_{p}$ represents the aerodynamic efficiency of the turbine, which approached in this work by the expression bellow [9]:

$$
C_{p}=0.5109\left(\left(\frac{116}{\lambda+0.08 \beta}-\frac{0.406}{\beta^{3}+1}\right)-0.4 \beta-5\right) \cdot \exp \left(\left(\frac{-0.0735}{(\lambda+0.08 \beta) \cdot\left(\beta^{3}+1\right)}\right)+21 \cdot \lambda\right)
$$

Where, $\beta$ the angle of orientation of the blades and $\lambda$ is the tip speed ratio. Moreover, the aerodynamic torque $C_{h}$ is obtained from $P_{h}$ by [9]:

$$
C_{h}=\frac{P_{h}}{\Omega_{t}}=C_{p}(\lambda, \beta) \cdot \frac{\rho A v^{3}}{2 \Omega_{T}}
$$

Neglecting the elasticity, friction and energy losses. The gearbox that is used to adapt the rotational speed $\Omega_{T}$ to that of the generator $\Omega_{m}$ can be modelled using G a gain ratio as follows:

$$
\Omega_{\text {mec }}=\mathrm{G} \cdot \Omega_{\mathrm{T}} ; \mathrm{C}_{\mathrm{h}}=\mathrm{G} \cdot \mathrm{C}_{\mathrm{g}}
$$

Finally, the model is completed by the fundamental equation of dynamic [13]:

$$
\mathrm{J}_{\mathrm{g}} \frac{\mathrm{d} \Omega_{\mathrm{mec}}}{\mathrm{dt}}=\mathrm{C}_{\mathrm{g}}-\mathrm{C}_{\mathrm{em}}-\mathrm{f} \cdot \Omega_{\mathrm{mec}}
$$

\subsection{DFIG Model}

The DFIG model is established using the dynamic equations of the stator and rotor currents, voltages, and fluxes represented in a two-phase dq reference frame [9, 14]:

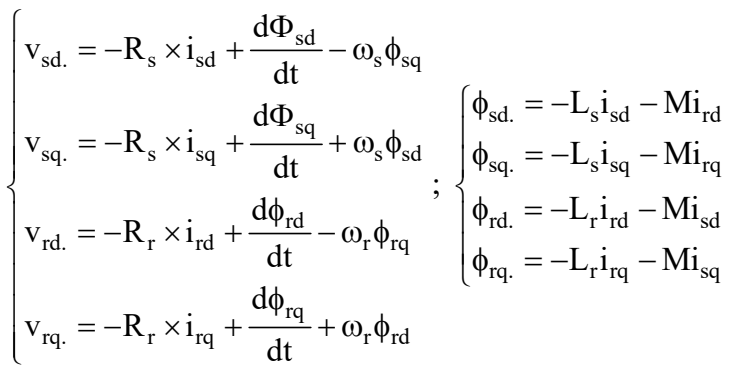

Where, $i_{s}, i_{r}, v_{s}, v_{r}, \Phi_{s}$ and $\Phi_{r}$ being respectively the stator and rotor currents, voltages, and generated fluxes. $\omega_{\mathrm{r}}$ and $\omega_{\mathrm{s}}$ represent the angular speed of the rotating field associated respectively to the rotor and to the stator $(\mathrm{rad} / \mathrm{s})$. Similarly, $R_{s}, L_{s}, R_{r}$, and $L_{r}$ are stator resistance and incuctance and rotor resistance and inductance respectively. Whereas, $M$ represents the mutual inductance. The reactive and active power as well as electromagnetic torque can be given by, with $\mathrm{p}$ being the pair of poles:

$$
\left\{\begin{array}{l}
P_{s}=\operatorname{Re}\left\{v_{s} i_{s}\right\}=\left(v_{s d} i_{s d}+v_{s q} i_{s q}\right) \\
Q_{s}=\operatorname{Im}\left\{v_{s} i_{s}\right\}=\left(v_{s q} i_{s d}-v_{s d} i_{s q}\right)
\end{array} ; C_{e m}=p \frac{M}{L_{s}}\left(\phi_{s q} i_{r d}-\phi_{s d} i_{r q}\right)\right.
$$




\subsection{FESS modeling and sizing}

FESS operates as an energy reserve that stores the energy in a kinetic form in a high-speed spinning mass coupled to the shaft of an electrical machine that provides an electromechanical interface between the flywheel and the system [1]. During the charging process, the machine works as a motor to speed up the rotational motion of the flywheel and therefore increasing the stored energy, then, the flywheel remains in the standby mode. Whereas, on-demand, the machine serves as a generator and decelerate the flywheel retrieving the stored energy into the system. The amount of energy stored in a flywheel $E_{f w}$ depends on the mass and the form (represented by flywheel inertia $\mathrm{J}_{\mathrm{fw}}$ ) and the rotational speed $\Omega_{\mathrm{fw}}[6]$ :

$$
\mathrm{E}_{\mathrm{fw}}=0.5 \cdot \mathrm{J}_{\mathrm{fw}} \Omega_{\mathrm{fw}}^{2}
$$

However, for safety reasons, the accessible kinetic energy $E_{f w 1}$ is limited by $\Omega_{\mathrm{fw}-\mathrm{max}}$ and $\Omega_{\mathrm{fw}-\mathrm{min}}$ which are respectively the maximum and minimum speed of the flywheel [15], giving that:

$$
\mathrm{E}_{\mathrm{fw} 1}=0.5 \cdot \mathrm{J}_{\mathrm{fw}}\left(\Omega_{\mathrm{fw}-\max }^{2}-\Omega_{\mathrm{fw}-\mathrm{min}}^{2}\right)
$$

The flywheel inertia is determined using the expression below, after selecting the storage system maximum power capacity stored during a certain $\Delta \mathrm{t}$, which is identical to the electrical motor rated power $P_{r-I M}$. Which in this application, considered lower than $20 \%$ the DFIG based wind turbine rated power:

$$
\mathrm{J}_{\mathrm{fw}}=\frac{2 \cdot \mathrm{E}_{\mathrm{fw} 1}}{\left(\Omega_{\mathrm{fw}-\max }^{2}-\Omega_{\mathrm{fw}-\min }^{2}\right)}=\frac{2 \cdot \mathrm{P}_{\mathrm{r}-\mathrm{IM}} \Delta \mathrm{t}}{\left(\Omega_{\mathrm{fw}-\max }^{2}-\Omega_{\mathrm{fw}-\min }^{2}\right)}
$$

In this work, the flywheel exchanges the energy with the system by means of an induction machine (IM). It is essential for the IM to operate in its field-weakening region, at a rotational speed ranging between 1500 and $3000 \mathrm{rpm}$, where its rated power is always available [1]. Therefore, the regulation of the flux $\varphi_{r d}$ is conducted in accordance with the following control law:

$$
\varphi_{\mathrm{r}-\mathrm{ref}}=\left\{\begin{array}{l}
\varphi_{\mathrm{r}-\text { rated }}=\frac{\mathrm{L}_{\mathrm{r}}}{\mathrm{M}} \frac{\sqrt{3} \mathrm{~V}_{\mathrm{s}}}{\omega_{\mathrm{s}}} ; \text { if } \quad\left|\Omega_{\mathrm{m}}\right| \leq\left|\Omega_{\mathrm{r}}\right| \\
\varphi_{\mathrm{r}-\text { rated }} \frac{\Omega_{\mathrm{r}}}{\left|\Omega_{\mathrm{m}}\right|} ; \text { if } \quad\left|\Omega_{\mathrm{m}}\right| \geq\left|\Omega_{\mathrm{r}}\right|
\end{array}\right.
$$

Where, $\varphi_{r-\text { rated }}$ and $\varphi_{s-\text { rated }}$ are respectively the rotor and the stator rated fluxes, $\Omega_{m}$ and $\Omega_{r}$ being the measured and the rated rotational speed of the $\mathrm{IM}$, and $\mathrm{V}_{s}$ is the stator rated voltage.

\section{PROPOSED CONTROL STRATEGIES}

\subsection{MSC control}

In order to decouple the control of stator reactive and active powers, a field oriented control scheme is adopted, aligning the d-axis with the stator flux $\left(\Phi_{s d}=\Phi_{s} ; \Phi_{s d}=0\right)$. Moreover, by neglecting the stator resistance, which is a rational approximation for high power generators [9], we determine the state model of the DFIG as follows:

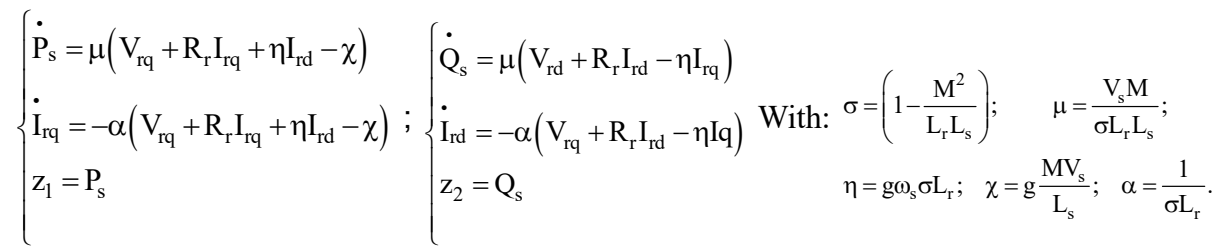

The backstepping (BS) basically uses the so-called (virtual control variables (VCVs)) to systematically dissacociate a nonlinear complex control scheme into simpler design problem [9]. The control design is divided into multiple steps. In every step, we virtually deal with a single input single output subsystem, so that each step provides a reference for the next one. The control law that guarantees the overall

Robust coordinated control using backstepping of flywheel energy storage system ... (Mohamed Nadour) 
system behaviour and stability can be built up in a constructive manner using Lyapunov functions. As it is shown in Figure 2 The block diagram of DSC control involves an open loop MPPT [16] used to establish the optimal active power reference in order to maximize the converted power by adjusting the wind turbine mechanical to its optimal value, and two serial control loops. The outer loop provides the VCVs (the references of currents) via the reactive and active power control. While the inner loop provides the actual control variables (rotor voltages) $[17,18]$.

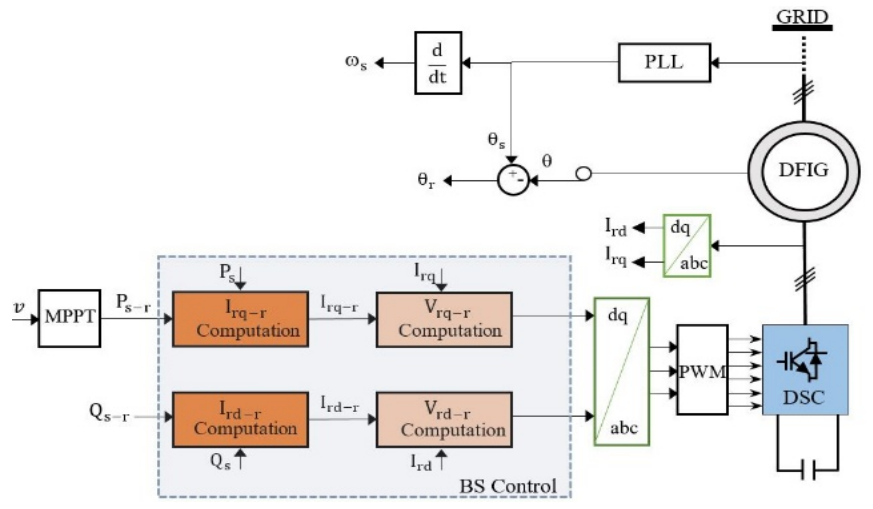

Figure 2. DSC control

\section{a) Currents references computation}

First, we define the errors variables, with $P_{s-r}$ and $Q_{s-r}$ being respectively the references of the stator reactive and active power. Then we select the chosen Lyapunov functions (LFs) such that:

$$
\left\{\begin{array}{l}
\mathrm{e}_{1}=\mathrm{P}_{\mathrm{s}-\mathrm{r}}-\mathrm{P}_{\mathrm{s}} \rightarrow \dot{\mathrm{e}}_{1}=\dot{\mathrm{P}}_{\mathrm{s}-\mathrm{r}-\mathrm{P}_{\mathrm{s}}} \quad \dot{\mathrm{e}}_{2}=\dot{\mathrm{Q}}_{\mathrm{s}-\mathrm{r}}-\mathrm{Q}_{\mathrm{s}} \rightarrow \dot{\mathrm{e}}_{2}=\dot{\mathrm{Q}}_{\mathrm{s}-\mathrm{r}}-\dot{\mathrm{Q}}_{\mathrm{s}}
\end{array} \quad \frac{1}{2} \mathrm{e}_{1}^{2} \quad \mathrm{~V}_{2}=\frac{1}{2} \mathrm{e}_{2}^{2}\right.
$$

The derivative of Lyapunov function can be written:

$$
\left\{\begin{array}{l}
\dot{\mathrm{V}}_{1 .}=\dot{\mathrm{e}}_{1} \cdot \mathrm{e}_{1}=\mathrm{e}_{1}\left(\dot{\mathrm{P}}_{\mathrm{s}-\mathrm{r}}-\mu\left(\mathrm{V}_{\mathrm{rq}}+\mathrm{R}_{\mathrm{r}} \mathrm{I}_{\mathrm{rq}}+\eta \mathrm{I}_{\mathrm{rd}}-\chi\right)\right) \\
\dot{\mathrm{V}}_{2 .}=\dot{\mathrm{e}}_{2} \cdot \mathrm{e}_{2}=\mathrm{e}_{2}\left(\dot{\mathrm{Q}}_{\mathrm{s}-\mathrm{r}}-\mu\left(\mathrm{V}_{\mathrm{rd}}+\mathrm{R}_{\mathrm{r}} \mathrm{I}_{\mathrm{rd}}-\eta \mathrm{I}_{\mathrm{rd}}\right)\right)
\end{array}\right.
$$

According to the BS theory, $\dot{\mathrm{V}}_{1}$ and $\dot{\mathrm{V}}_{2}$ must be strictly negative to ensure the stability of this first step. Thus, $\dot{\mathrm{V}}_{1}=-\mathrm{b}_{\mathrm{s} 1} \mathrm{e}_{1}^{2}$ and $\dot{\mathrm{V}}_{2}=-\mathrm{b}_{\mathrm{s} 2} \mathrm{e}_{2}^{2}$. The currents references are obtained using (14):

$$
\left\{\begin{array}{l}
\mathrm{I}_{\mathrm{rq}-\mathrm{r}}=\frac{1}{\mu \mathrm{R}_{\mathrm{r}}}\left(\dot{\mathrm{P}}_{\mathrm{s}-\mathrm{r}}+\mathrm{b}_{\mathrm{s} 1} \mathrm{e}_{1}\right)-\frac{1}{\mathrm{R}_{\mathrm{r}}}\left(\mathrm{V}_{\mathrm{rq}}+\eta \mathrm{I}_{\mathrm{rd}}-\chi\right) \\
\mathrm{I}_{\mathrm{rd}-\mathrm{r}}=\frac{1}{\mu \mathrm{R}_{\mathrm{r}}}\left(\dot{\mathrm{Q}}_{\mathrm{s}-\mathrm{r}}+\mathrm{b}_{\mathrm{s} 2} \mathrm{e}_{2}\right)-\frac{1}{\mathrm{R}_{\mathrm{r}}}\left(\mathrm{V}_{\mathrm{rd}}-\eta \mathrm{I}_{\mathrm{rd}}\right)
\end{array}\right.
$$

\section{b) Rotor voltages computation}

We define the errors variables, noting that the VCVs determined by (15) are the desired variable in this step, and we select the LFs for this step such that:

$$
\left\{\begin{array}{l}
\mathrm{e}_{3}=\mathrm{I}_{\mathrm{rq}-\mathrm{r}}-\mathrm{I}_{\mathrm{rq}} \rightarrow \dot{\mathrm{e}}_{3}=\dot{\mathrm{I}}_{\mathrm{rq}-\mathrm{r}-\mathrm{I}_{\mathrm{rq}}} \\
\mathrm{e}_{4}=\mathrm{I}_{\mathrm{rd}-\mathrm{r}}-\mathrm{I}_{\mathrm{rd}} \rightarrow \mathrm{e}_{3}=\frac{1}{2}\left(\mathrm{e}_{1}^{2}+\mathrm{e}_{3 \mathrm{rd}-\mathrm{r}-\mathrm{I}_{\mathrm{rd}}}\right) \quad \mathrm{V}_{4 .}=\frac{1}{2}\left(\mathrm{e}_{2}^{2}+\mathrm{e}_{4}^{2}\right)
\end{array}\right.
$$


In order to insure a stable tracking performance the derivative of the LFs must be negative. Finally, owing to (16) the control voltages are given by:

$$
\text { -a) }\left\{\begin{array}{l}
\dot{\mathrm{V}}_{1}=-\mathrm{b}_{\mathrm{s} 1} \mathrm{e}_{1}^{2}-\mathrm{b}_{\mathrm{s} 3} \mathrm{e}_{3}^{2} \prec 0 \\
\dot{\mathrm{V}}_{4}=-\mathrm{b}_{\mathrm{s} 2} \mathrm{e}_{2}^{2}-\mathrm{b}_{\mathrm{s} 4} \mathrm{e}_{4}^{2} \prec 0
\end{array} ;-\mathrm{b}\right)\left\{\begin{array}{l}
\mathrm{V}_{\mathrm{rq}-\mathrm{r}}=\left\{-\mathrm{b}_{\mathrm{s} 3} \mathrm{e}_{3}-\dot{\mathrm{I}}_{\mathrm{rq}-\mathrm{r}}-\mu \mathrm{e}_{1}\right\} \frac{1}{\alpha}-\left\{\mathrm{R}_{\mathrm{r}} \mathrm{I}_{\mathrm{rq}}+\eta \mathrm{I}_{\mathrm{rd}}+\chi\right\} \\
\mathrm{V}_{\mathrm{rd}-\mathrm{r}}=\left\{-\mathrm{b}_{\mathrm{s} 4} \mathrm{e}_{4}-\dot{\mathrm{I}}_{\mathrm{rd}-\mathrm{r}}-\mu \mathrm{e}_{2}\right\} \frac{1}{\alpha}-\left\{\mathrm{R}_{\mathrm{r}} \mathrm{I}_{\mathrm{rd}}-\eta \mathrm{I}_{\mathrm{rd}}\right\}
\end{array}\right.
$$

Noting that $b_{\mathrm{s} 1}, b_{\mathrm{s} 2}, b_{\mathrm{s} 3}$ and $b_{\mathrm{s} 4}$ are positive constants called the BS coefficients, used to ensure a fast dynamic response and the stability of the overall system.

\subsection{GSC control}

The GSC is connected to the grid through a filter (resistor-inductor circuit $R_{f}, L_{f}$ ). Figure 3 shows the block diagram of NSC control that involves two consecutive control loops. The outer loop provides the VCVs (the references of the filter output currents $\left(I_{f d-r}\right.$ and $\left.I_{f q-r}\right)$ via the reactive and active power control. While the inner loop provides the actual control variables (the filter output voltages $V_{f d-r}$ and $V_{f q-r}$ )). This system can be represented in a dq reference frame by the following equation [19]:

$$
\left\{\begin{array}{l}
\mathrm{V}_{\mathrm{td} .}=\mathrm{R}_{\mathrm{t}} \mathrm{I}_{\mathrm{td}}+\mathrm{L}_{\mathrm{t}} \frac{\mathrm{dI}_{\mathrm{td}}}{\mathrm{dt}}-\omega_{\mathrm{s}} \mathrm{L}_{\mathrm{t}} \mathrm{I}_{\mathrm{tq}}+\mathrm{V}_{\mathrm{sd}} \\
\mathrm{V}_{\mathrm{tq} .}=\mathrm{R}_{\mathrm{t}} \mathrm{I}_{\mathrm{tq}}+\mathrm{L}_{\mathrm{t}} \frac{\mathrm{dI} \mathrm{tq}}{\mathrm{dt}}-\omega_{\mathrm{s}} \mathrm{L}_{\mathrm{t}} \mathrm{I}_{\mathrm{td}}+\mathrm{V}_{\mathrm{sq}}
\end{array}\right.
$$

A vector control is used to achieve an independent control of the active power and the reactive power and exchanged between the NSC and the grid. By aligning the q-axis of the park reference frame with network voltage equivalent vector, thus, $V_{s d}=0$ and $V_{s q}=V_{s}$. , the model of the system can be determined as follows:

$$
\left\{\begin{array}{l}
\dot{\mathrm{P}}_{\mathrm{t} .}=\frac{\mathrm{V}_{\mathrm{s}}}{\mathrm{L}_{\mathrm{t}}}\left(\mathrm{V}_{\mathrm{tq}}-\mathrm{R}_{\mathrm{t}} \times \mathrm{I}_{\mathrm{tq}}-\omega_{\mathrm{s}} \mathrm{L}_{\mathrm{t}} \mathrm{I}_{\mathrm{td}}-\mathrm{V}_{\mathrm{s}}\right) \\
\dot{\mathrm{I}}_{\mathrm{tq} .}=\frac{1}{\mathrm{~L}_{\mathrm{t}}}\left(\mathrm{V}_{\mathrm{tq}}-\mathrm{R}_{\mathrm{t}} \times \mathrm{I}_{\mathrm{tq}}-\omega_{\mathrm{s}} \mathrm{L}_{\mathrm{t}} \mathrm{I}_{\mathrm{td}}-\mathrm{V}_{\mathrm{s}}\right) \\
\mathrm{z}_{1 .}=\mathrm{P}_{\mathrm{t} .}
\end{array} ;\left\{\begin{array}{l}
\dot{\mathrm{Q}}_{\mathrm{t} .}=\frac{\mathrm{V}_{\mathrm{s}}}{\mathrm{L}_{\mathrm{t}}}\left(\mathrm{V}_{\mathrm{td}}-\mathrm{R}_{\mathrm{t}} \times \mathrm{I}_{\mathrm{td}}-\omega_{\mathrm{s}} \mathrm{L}_{\mathrm{t}} \mathrm{I}_{\mathrm{tq}}\right) \\
\dot{\mathrm{I}}_{\mathrm{td} .}=\frac{1}{\mathrm{~L}_{\mathrm{t}}}\left(\mathrm{V}_{\mathrm{td}}-\mathrm{R}_{\mathrm{t}} \times \mathrm{I}_{\mathrm{td}}-\omega_{\mathrm{s}} \mathrm{L}_{\mathrm{t}} \mathrm{I}_{\mathrm{tq}}\right) \\
\mathrm{z}_{2 .}=\mathrm{Q}_{\mathrm{t} .}
\end{array}\right.\right.
$$

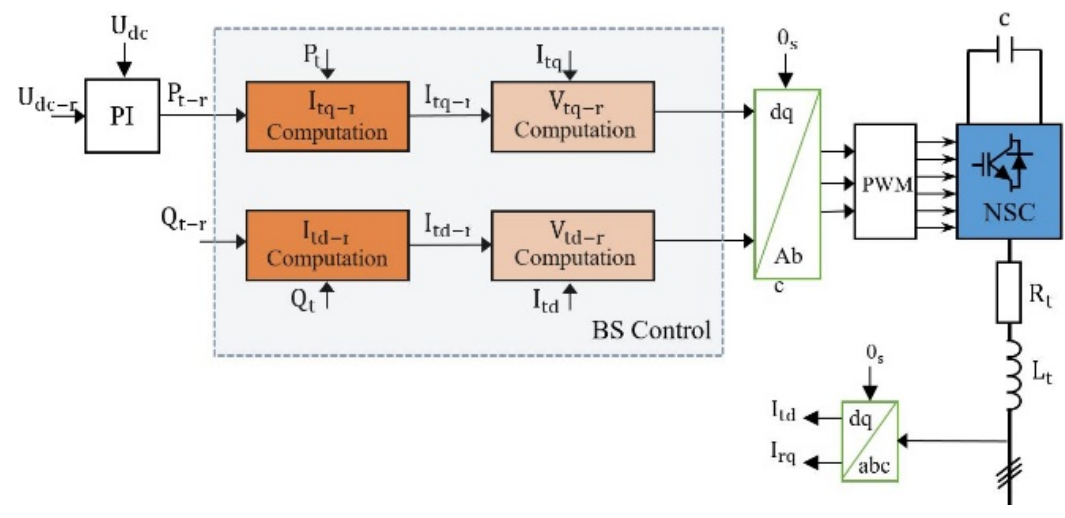

Figure 3. NSC control

\section{a) Currents references computation}

We define $\left(\mathrm{e}_{1}, \mathrm{e}_{2}\right)$ representing the errors variables, we choose the LFs such that: 


$$
\left\{\begin{array}{l}
\mathrm{e}_{1}=\mathrm{P}_{\mathrm{t}-\mathrm{r}}-\mathrm{P}_{\mathrm{t}} \rightarrow \dot{\mathrm{e}}_{1}=\dot{\mathrm{P}}_{\mathrm{t}-\mathrm{r}}-\dot{\mathrm{P}}_{\mathrm{t}} \\
\mathrm{e}_{2}=\mathrm{Q}_{\mathrm{t}-\mathrm{r}}-\mathrm{Q}_{\mathrm{t}} \rightarrow \dot{\mathrm{e}}_{2}=\dot{\mathrm{Q}}_{\mathrm{t}-\mathrm{r}}-\dot{\mathrm{Q}}_{\mathrm{t}}
\end{array} ;\left\{\begin{array}{l}
\mathrm{V}_{1}=\frac{1}{2} \mathrm{e}_{1}^{2} \\
\mathrm{~V}_{1}=\frac{1}{2} \mathrm{e}_{1}^{2}
\end{array}\right.\right.
$$

Likewise, applying the same principle used for the DSC control, the VCVs that guarantee a stable tracking in the first control loop can be determined such that:

$$
\text { -a) }\left\{\begin{array}{l}
\dot{\mathrm{V}}_{1}=-\mathrm{b}_{\mathrm{s} 1}^{\prime} \mathrm{e}_{1}^{2} \prec 0 \\
\dot{\mathrm{V}}_{4}=-\mathrm{b}_{\mathrm{s} 2}^{\prime} \mathrm{e}_{2}^{2} \prec 0
\end{array} ;-\mathrm{b}\right)\left\{\begin{array}{l}
\mathrm{I}_{\mathrm{tq}-\mathrm{r} .}=\frac{1}{\mathrm{R}_{\mathrm{f}}}\left[\frac{\mathrm{L}_{\mathrm{t}}}{\mathrm{V}_{\mathrm{s}}}\left(-\dot{\mathrm{P}}_{\mathrm{t}-\mathrm{r}}-\mathrm{b}_{\mathrm{s} 1}^{\prime} \mathrm{e}_{1}\right)+\left(\mathrm{V}_{\mathrm{tq}}-\omega_{\mathrm{s}} \mathrm{L}_{\mathrm{t}} \mathrm{I}_{\mathrm{td}}-\mathrm{V}_{\mathrm{s}}\right)\right] \\
\mathrm{I}_{\mathrm{td}-\mathrm{r} \mathrm{r}}=\frac{1}{\mathrm{R}_{\mathrm{f}}}\left[\frac{\mathrm{L}_{\mathrm{t}}}{\mathrm{V}_{\mathrm{s}}}\left(-\dot{\mathrm{Q}}_{\mathrm{t}-\mathrm{r}}-\mathrm{b}_{\mathrm{s} 2}^{\prime} \mathrm{e}_{2}\right)+\left(\mathrm{V}_{\mathrm{td}}+\omega_{\mathrm{s}} \mathrm{L}_{\mathrm{t}} \mathrm{I}_{\mathrm{tq}}\right)\right]
\end{array}\right.
$$

\section{b) Rotor voltages computation}

The VCVs determined previously are the desired variable for this step. We define :

$$
\left\{\begin{array}{l}
\mathrm{e}_{3}=\mathrm{I}_{\mathrm{tq}-\mathrm{r}}-\mathrm{I}_{\mathrm{tq}} \rightarrow \dot{\mathrm{e}}_{3}=\dot{\mathrm{I}}_{\mathrm{tq}-\mathrm{r}-\mathrm{I}_{\mathrm{tq}}} \\
\mathrm{e}_{4}=\mathrm{I}_{\mathrm{td}-\mathrm{r}}-\mathrm{I}_{\mathrm{td}} \rightarrow \dot{\mathrm{e}}_{4}=\dot{\mathrm{I}}_{\mathrm{td}-\mathrm{r}-\dot{\mathrm{I}}_{\mathrm{td}}}
\end{array} ;\left\{\begin{array}{c}
\mathrm{V}_{3}=\frac{1}{2}\left(\mathrm{e}_{1}^{2}+\mathrm{e}_{3}^{2}\right) \\
\mathrm{V}_{4}=\frac{1}{2}\left(\mathrm{e}_{2}^{2}+\mathrm{e}_{4}^{2}\right)
\end{array}\right.\right.
$$

Similarly, the control law that ensures global stability of the system is written such :

$$
\text { -a) }\left\{\begin{array}{l}
\dot{V}_{3}=-b_{s 1}^{\prime} e_{1}^{2}-b_{s 3}^{\prime} e_{3}^{2} \prec 0 \\
\dot{V}_{4}=-b_{s 2}^{\prime} e_{2}^{2}-b_{s 4}^{\prime} e_{4}^{2} \prec 0
\end{array} ;-b\right)\left\{\begin{array}{l}
V_{\mathrm{fq}-\mathrm{r}}=\left\{-b_{s 2} e_{2}-\dot{I}_{\mathrm{tq}-\mathrm{r}}-\frac{V_{\mathrm{s}}}{\mathrm{L}_{\mathrm{t}}} \mathrm{e}_{1}\right\} \mathrm{L}_{\mathrm{t}}-\left\{\mathrm{R}_{\mathrm{t}} \mathrm{I}_{\mathrm{tq}}+\omega_{\mathrm{s}} \mathrm{L}_{\mathrm{t}} \mathrm{I}_{\mathrm{td}}\right\} \\
\mathrm{V}_{\mathrm{td}-\mathrm{r}}=\left\{-\mathrm{b}_{\mathrm{s} 4} \mathrm{e}_{4}-\dot{\mathrm{I}}_{\mathrm{td}-\mathrm{r}}-\frac{\mathrm{V}_{\mathrm{s}}}{\mathrm{L}_{\mathrm{t}}} \mathrm{e}_{3}\right\} \mathrm{L}_{\mathrm{t}}-\left\{\mathrm{R}_{\mathrm{t}} \mathrm{I}_{\mathrm{td}}+\omega_{\mathrm{s}} \mathrm{L}_{\mathrm{t}} \mathrm{I}_{\mathrm{tq}}\right\}
\end{array}\right.
$$

\section{c) DC-link viltage control}

Neglecting the converters losses. With $\mathrm{P}_{\mathrm{r}}, \mathrm{P}_{\mathrm{c}}$ and $\mathrm{P}_{\mathrm{st}}$ being respectively the rotor, the DC-bus and the FESS active power Figure 4 We have:

$$
\begin{aligned}
& P_{c}=P_{t}-P_{s}-P_{s t} \\
& \text { With: } P_{c}=\frac{d}{d t}\left(\frac{1}{2} C U_{d c}^{2}(t)\right)=C U_{d c}(t) \cdot \frac{d U_{d c}(t)}{d t}
\end{aligned}
$$

According to (24) and (25), we write:

$$
I_{c}=C \cdot \frac{d U_{d c}(t)}{d t}=\frac{P_{t}-P_{r}-P_{s t}}{U_{d c}(t)}
$$

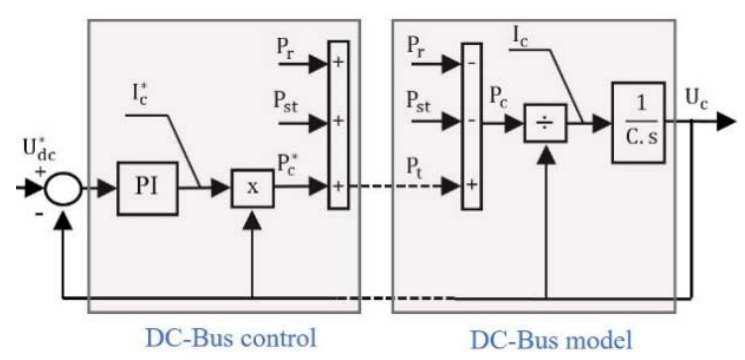

Figure 4. DC-link voltage control 


\subsection{FSC control}

The FSC control it is used to manage the storage device operation so as to store the energy when available, and to restore it back to the system in the opposite case. The block diagram of FSC control is shown in Figure 5 it involves two control loops i.e. the outer loop that provides the VCVs (the references of the stator output currents $I_{s d-r}$ and $I_{s q-r}$ ) via the rotational speed and direct flux control, and the inner loop that provides the actual control variables (the output voltages $V_{s d-r}$ and $\left.V_{s q-r}\right)$ ).

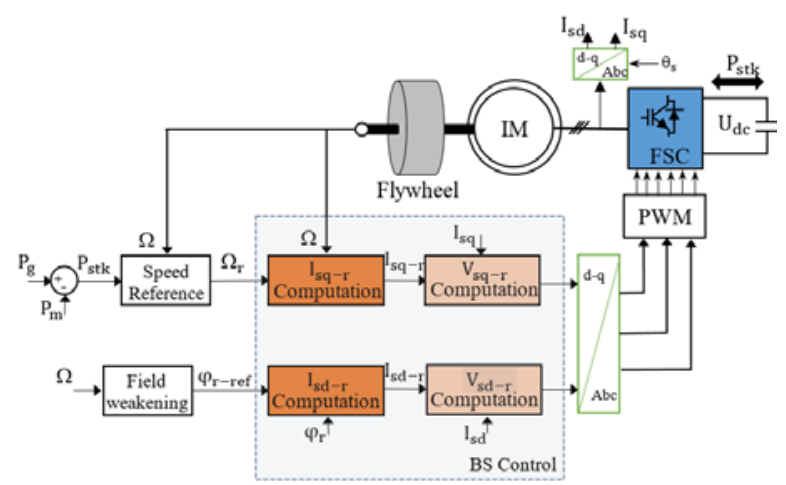

Figure 5. Block diagram of the FSC control

The reactive and active power at the point of common coupling (PCC) are given by:

$$
\begin{gathered}
\left\{\begin{array}{l}
\mathrm{P}_{\mathrm{g}}=\mathrm{P}_{\mathrm{s}}+\mathrm{P}_{\mathrm{t}} \\
\mathrm{Q}_{\mathrm{g}}=\mathrm{Q}_{\mathrm{s}}+\mathrm{P}_{\mathrm{t}}
\end{array}\right. \\
\text { We define: }\left\{\begin{array}{l}
\mathrm{P}_{\mathrm{m}}=\mathrm{P}_{\mathrm{s}}+\mathrm{P}_{\mathrm{r}} \\
\mathrm{Q}_{\mathrm{m}}=\mathrm{Q}_{\mathrm{s}}+\mathrm{P}_{\mathrm{r}}
\end{array}\right.
\end{gathered}
$$

Where $\left(Q_{s} ; P_{s}\right),\left(Q_{r} ; P_{r}\right)$ and $\left(Q_{t} ; P_{t}\right)$ being the reactive and active power provided in the stator, the rotor and the filter, respectively. Knowing the adjusted power $\mathrm{P}_{\mathrm{g}-\mathrm{r}}$ desired to be injected into the grid, the power reference of the FESS control can be determined using the following expression [6]:

$$
\mathrm{P}_{\mathrm{stk}}=\mathrm{P}_{\mathrm{g}-\mathrm{r}}-\mathrm{P}_{\mathrm{m}}
$$

Therefore, with $\mathrm{E}_{\mathrm{fw} 0}$ being the energy initially stored in the flywheel. We determine the total power stored in the flywheel using:

$$
E_{f w-r}=E_{f w 0}+\int P_{s t k} d t
$$

Finally, the speed reference can be deduced using the expression (11):

$$
\Omega_{\mathrm{fw}-\mathrm{r}}=\sqrt{\frac{2 \cdot \mathrm{E}_{\mathrm{fw}-\mathrm{r}}}{\mathrm{J}_{\mathrm{fw}}}}
$$

In order to achieve a separate control the rotational speed and the flux component of the IM, we adopted a field oriented control scheme, by aligning the d-axis of the park reference frame with rotor flux, such that $\varphi_{r d}=\varphi_{r}, \varphi_{r q}=0$. Based on the IM model given in [20] we determine the stat model of the IM as follows:

Robust coordinated control using backstepping of flywheel energy storage system ... (Mohamed Nadour) 


$$
\left\{\begin{array}{l}
\dot{\Omega}=\frac{\mu}{J} \varphi_{\mathrm{r}} \mathrm{I}_{\mathrm{sq}}-\frac{\mathrm{f}_{\mathrm{r}}}{\mathrm{J}} \Omega-\frac{\mathrm{C}_{\mathrm{r}}}{\mathrm{J}} \\
\dot{\mathrm{I}}_{\mathrm{sq}}=-\eta \mathrm{I}_{\mathrm{sq}}-\mathrm{p} \beta \Omega \mathrm{I}_{\mathrm{sd}}-\mathrm{p} \Omega \mathrm{I}_{\mathrm{sd}}-\alpha \mathrm{M} \frac{\mathrm{I}_{\mathrm{sd}} \mathrm{I}_{\mathrm{sq}}}{\varphi_{\mathrm{r}}}-\frac{\mathrm{V}_{\mathrm{sq}}}{\sigma \mathrm{L}_{\mathrm{s}}} \\
\mathrm{y}_{1}=\Omega
\end{array} ;\left\{\begin{array}{l}
\dot{\varphi}_{\mathrm{r}}=-\alpha \varphi_{\mathrm{rd}}+\alpha M \mathrm{I}_{\mathrm{sd}} \\
\dot{\mathrm{I}}_{\mathrm{sd}}=-\eta \mathrm{I}_{\mathrm{sd}}+\alpha \beta \varphi_{\mathrm{rd}}+\mathrm{p} \Omega \mathrm{I}_{\mathrm{sq}}-\alpha \mathrm{M} \frac{\mathrm{I}_{\mathrm{sq}}^{2}}{\varphi_{\mathrm{rd}}}-\frac{\mathrm{V}_{\mathrm{sq}}}{\sigma \mathrm{L}_{\mathrm{s}}} \\
\mathrm{y}_{2}=\varphi_{\mathrm{r}}
\end{array}\right.\right.
$$

Where, $\mathrm{p}$ represents the pole pairs and:

$$
\sigma=\left(1-\frac{\mathrm{M}^{2}}{\mathrm{~L}_{\mathrm{r}} \mathrm{L}_{\mathrm{s}}}\right) ; \quad \mu=\frac{\mathrm{pM}}{\mathrm{L}_{\mathrm{r}}} ; \quad \eta=\frac{\mathrm{M}^{2} \mathrm{R}_{\mathrm{r}}+\mathrm{L}_{\mathrm{r}}^{2} \mathrm{R}_{\mathrm{r}}}{\sigma \mathrm{L}_{\mathrm{s}} \mathrm{L}_{\mathrm{r}}^{2}} ; \quad \beta=\frac{\mathrm{M}}{\sigma \mathrm{L}_{\mathrm{r}} \mathrm{L}_{\mathrm{s}}} ; \quad \alpha=\frac{\mathrm{R}_{\mathrm{r}}}{\mathrm{L}_{\mathrm{r}}} .
$$

\section{a) Currents references computation}

We define $\left(\mathrm{e}_{1}, \mathrm{e}_{2}\right)$ representing the errors variables and we select the lyapunov function such that:

$$
\left\{\begin{array}{l}
\mathrm{e}_{1}=\Omega_{\mathrm{r}}-\Omega \rightarrow \dot{\mathrm{e}}_{1}=\dot{\Omega}_{\mathrm{r}}-\dot{\Omega} \\
\mathrm{e}_{2}=\varphi_{\mathrm{r}-\mathrm{ref}}-\varphi_{\mathrm{r}} \rightarrow \dot{\mathrm{e}}_{2}=\dot{\varphi}_{\mathrm{r}-\mathrm{ref}}-\dot{\varphi}_{\mathrm{r}}
\end{array} ;\left\{\begin{array}{l}
\mathrm{v}_{1}=\frac{1}{2} \mathrm{e}_{1}^{2} \\
\mathrm{v}_{2}=\frac{1}{2} \mathrm{e}_{2}^{2}
\end{array}\right.\right.
$$

Likewise, applying the same principle used for the MSC-GSC control, the VCVs that guarantee the asymptotic stability of the first control loop can be determined such that:

$$
\text { -a) }\left\{\begin{array}{l}
\dot{\mathrm{V}}_{1}=-\mathrm{b}_{\mathrm{s} 1}^{\prime \prime} \mathrm{e}_{1}^{2} \prec 0 \\
\dot{\mathrm{V}}_{2}=-\mathrm{b}_{\mathrm{s} 2}^{\prime \prime} \mathrm{e}_{2}^{2} \prec 0
\end{array} ;-\mathrm{b}\right)\left\{\begin{array}{l}
\mathrm{I}_{\mathrm{sq}-\mathrm{r}}=\frac{1}{\varphi_{\mathrm{r}}} \frac{\mathrm{J}}{\mu}\left(\mathrm{k}_{1}^{\prime \prime} \mathrm{e}_{1}+\dot{\Omega}_{\mathrm{r}}+\frac{\mathrm{f}_{\mathrm{r}}}{\mathrm{J}} \Omega+\frac{\mathrm{C}_{\mathrm{r}}}{\mathrm{J}}\right) \\
\mathrm{I}_{\mathrm{sd}-\mathrm{r}}=\frac{1}{\alpha \mathrm{M}}\left(\mathrm{k}_{2}^{\prime \prime} \mathrm{e}_{2}+\dot{\varphi}_{\mathrm{r}-\mathrm{ref}}+\alpha \varphi_{\mathrm{r}}\right)
\end{array}\right.
$$

\section{b) Rotor voltages computation}

Again, the VCVs determined previously are the desired input variable in this step. We define the errors $\left(\mathrm{e}_{3}, \mathrm{e}_{4}\right)$ and Lyapunov function such that:

$$
\left\{\begin{array}{l}
\mathrm{e}_{3}=\mathrm{I}_{\mathrm{rq}-\mathrm{r}}-\mathrm{I}_{\mathrm{rq}} \rightarrow \dot{\mathrm{e}}_{3}=\dot{\mathrm{I}}_{\mathrm{rq}-\mathrm{r}}-\dot{\mathrm{I}}_{\mathrm{rq}} \\
\mathrm{e}_{4}=\mathrm{I}_{\mathrm{rd}-\mathrm{r}}-\mathrm{I}_{\mathrm{rd}} \rightarrow \dot{\mathrm{e}}_{4}=\dot{\mathrm{I}}_{\mathrm{rd}-\mathrm{r}}-\dot{\mathrm{I}}_{\mathrm{rd}}
\end{array} ;\left\{\begin{array}{l}
\mathrm{V}_{3}=\frac{1}{2}\left(\mathrm{e}_{1}^{2}+\mathrm{e}_{3}^{2}\right) \\
\mathrm{V}_{4}=\frac{1}{2}\left(\mathrm{e}_{2}^{2}+\mathrm{e}_{4}^{2}\right)
\end{array}\right.\right.
$$

The control law that insures the stability of the overall system, can be determined by:

$$
\text { -a) }\left\{\begin{array}{l}
\dot{\mathrm{V}}_{3}=-\mathrm{b}_{\mathrm{s} 1}^{\prime \prime} \mathrm{e}_{1}^{2}-\mathrm{b}_{\mathrm{s} 3}^{\prime \prime} \mathrm{e}_{3}^{2} \prec 0 \\
\dot{\mathrm{V}}_{4}=-\mathrm{b}_{\mathrm{s} 2}^{\prime \prime} \mathrm{e}_{2}^{2}-\mathrm{b}_{\mathrm{s} 4}^{\prime \prime} \mathrm{e}_{4}^{2} \prec 0
\end{array} ;-\mathrm{b}\right)\left\{\begin{array}{l}
\mathrm{V}_{\mathrm{sq}-\mathrm{r}}=\sigma \mathrm{L}_{\mathrm{s}}\left(\dot{\mathrm{I}}_{\mathrm{rq}-\mathrm{r}}+\frac{\mu}{\mathrm{J}} \varphi_{\mathrm{r}} \mathrm{e}_{1}-\delta_{1}+\mathrm{b}_{\mathrm{s} 3}^{\prime \prime} \mathrm{e}_{3}\right) \\
\mathrm{V}_{\mathrm{sd}-\mathrm{r}}=\sigma \mathrm{L}_{\mathrm{s}}\left(\dot{\mathrm{I}}_{\mathrm{rd}-\mathrm{r}}+\alpha M \mathrm{Me}_{2}-\delta_{2}+\mathrm{b}_{\mathrm{s} 4}^{\prime \prime} \mathrm{e}_{4}\right)
\end{array}\right.
$$

Where: $\delta_{1}=-\eta I_{s q}-p \beta \Omega \varphi_{\mathrm{r}}-\mathrm{p} \Omega \mathrm{I}_{\mathrm{sd}}-\alpha \mathrm{M} \frac{\mathrm{I}_{\mathrm{sd}} \mathrm{I}_{\mathrm{sq}}}{\varphi_{\mathrm{r}}} \quad \delta_{2}=-\eta \mathrm{I}_{\mathrm{sd}}-\alpha \beta \varphi_{\mathrm{r}}-\mathrm{p} \Omega \mathrm{I}_{\mathrm{sq}}-\alpha \mathrm{M} \frac{\mathrm{I}_{\mathrm{sq}}^{2}}{\varphi_{\mathrm{r}}}$

\section{SIMULATION RESULTS}

Simulation studies are performed with the system characteristics presented in Table 1 in Appendix. All simulation are run with the same wind profile that varies around an average speed of $8.9 \mathrm{~m} / \mathrm{s}$ for a $50 \mathrm{sec}$ duration, as shown in Figure 6.

Int J Pow Elec \& Dri Syst, Vol. 10, No. 2, June 2019 : $1110-1122$ 
When using a MPPT strategy, the active power delivered by the wind turbine is corresponding to the cube of the wind speed. Meaning that a small variation in the wind causes a significant variation in the output power. Figure 7 shows the DFIG stator active power and and Figure 8 shows its reactive power curves respectively. In this work, the latter is maintained equal to zero in order keep a unitary power factor at PC. In brief, the results demonstrate the validness of the MSC proposed control scheme, being that the outputs encounter flawlessly their references and all tracking errors converge to zero asymptotically. Moreover, the reference of the FESS power $\mathrm{P}_{\text {stk-r }}$ determined using Eq.42, which corresponds to the difference between $\mathrm{P}_{\mathrm{g}-\mathrm{r}}$ which is the net power intended to be delivered to the grid and $\mathrm{P}_{\mathrm{m}}$ the total generated power, as it is shown in Figure 9. In Figure 10 and Figure 11, the results show the effectiveness of the FSC control scheme, given that the FESS output power $\mathrm{P}_{\text {stk }}$ and the instantaneous rotational speed $\Omega$ present an excellent tracking response. The storage device is initially charged with $E_{\mathrm{fw} 0}$ and rotate at an initial speed of $200 \mathrm{~m} / \mathrm{s}$, it accelerate to store energy when the output power $\mathrm{P}_{\text {stk }}$ is positive, and decelerate to generate it in the opposite case. Figure 12 and Figure 13 pinpoints the efficiency the GSC control strategy. Figure 12 illustrate the DC bus regulation, which is used to maintain a constant voltage, and Figure 13 shows that the reactive power $Q_{f}$ exchanged between the GSC and the electrical network converges to its reference that is likewise chosen to be zero.

The total active power injected to the power system $\mathrm{P}_{\mathrm{g}}$ with and without including the FESS support is shown in Figure 14. As expected, the power injected without the support of the storage device is highly fluctuating due to random nature of the wind. On the other hand, the quality of the output power generated by the arrangement (DFIG plus FESS) at the PCC is comparatively smoother, and $\mathrm{P}_{\mathrm{g}}$ remains at the designated reference $\mathrm{P}_{\mathrm{g}-\mathrm{r}}$ which chosen to be equal to $775 \mathrm{~kW}$ in this case of study. However, a low pass filter can be used to determine $\mathrm{P}_{\mathrm{g}-\mathrm{r}}$ for long-term FESS operation.

In order evaluate the improvement achieved by applying the proposed control algorithms, it is particularly important to analyze the system performance under parametric variation, since usually machines parameters are exposed to many inaccuracies due to the adopted identification methodology, measuring devices or several natural phenomena. Therefore, to demonstrate the system ability to react against this kind of disturbances, we compared the proposed backstepping control approach with conventional PI controllers for the MSC and the FSC control. This test, consist of modifying the DFIG's model parameters such that $\left(\mathrm{R}_{\mathrm{r}}^{\prime}=1.5 \mathrm{R}_{\mathrm{r}} ; \mathrm{L}_{\mathrm{r}}^{\prime}=1.2 \mathrm{~L}_{\mathrm{r}} ; \mathrm{L}_{\mathrm{s}}^{\prime}=1.2 \mathrm{~L}_{\mathrm{s}}\right)$ and the FESS-IM's model parameters in a way that $\left(\mathrm{R}_{\mathrm{s}}^{\prime \prime}=\right.$ $1.5 \mathrm{R}_{\mathrm{s}} ; \mathrm{R}_{\mathrm{r}}^{\prime}=1.5 \mathrm{R}_{\mathrm{r}}$ ). Figure 15, Figure 16 and Figure 17 show respectively the DFIG stator active $\mathrm{P}_{\mathrm{s}}$ and reactive power $\mathrm{Q}_{\mathrm{s}}$ and the FESS output power. Accordingly, the test confirm the robustness of the proposed backstepping control strategy compared to PI controllers. Being that the latter have shown high sensitivity towards parametric variation, a static error appears in the FESS-IM control, notably at the output power, whereas the performance has been completely deteriorated for the DFIG control. On the other hand, BS controllers present an exquisite disturbance rejection and all the outputs converge correctly to their designated references.

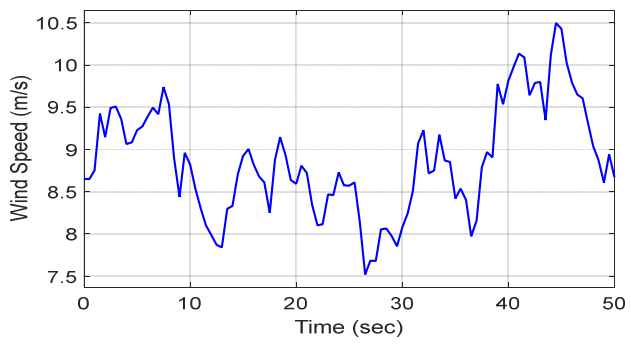

Figure 6: Wind speed profile

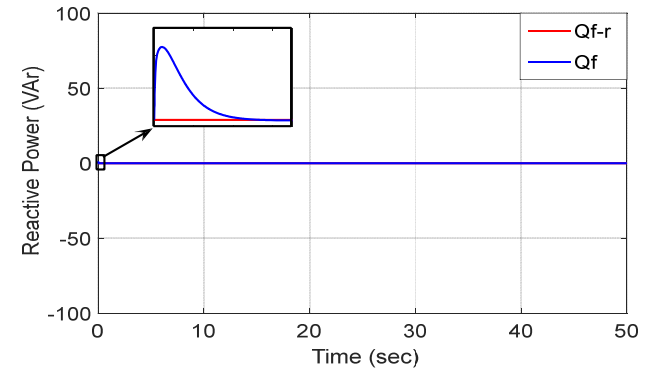

Figure 12. Reactive power at the output of GSC 


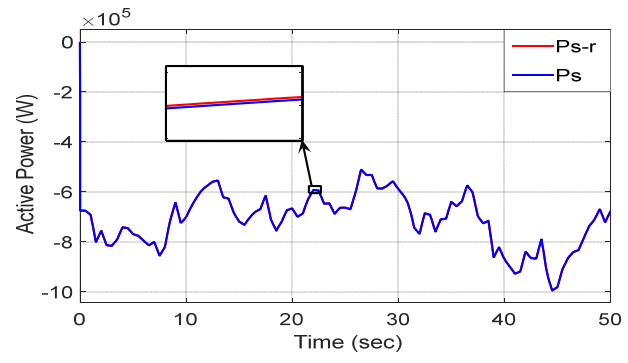

Figure 7. Active power of the DFIG

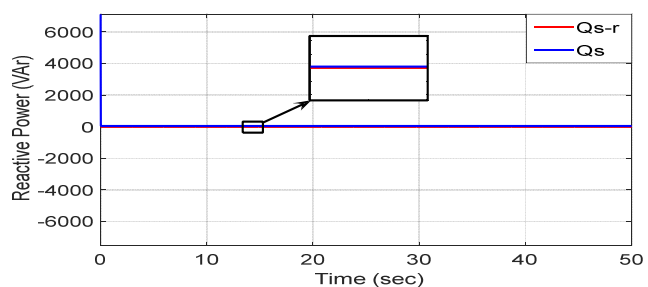

Figure 8. Reactive power of the DFIG

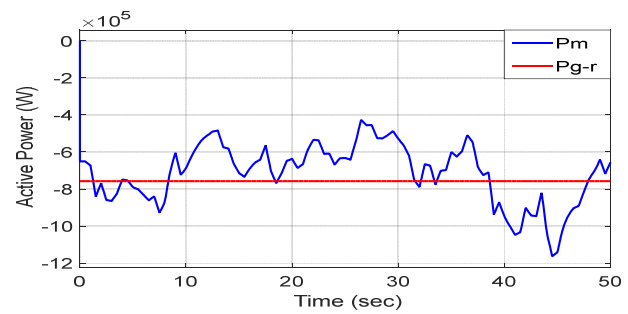

Figure 9. Operation principle

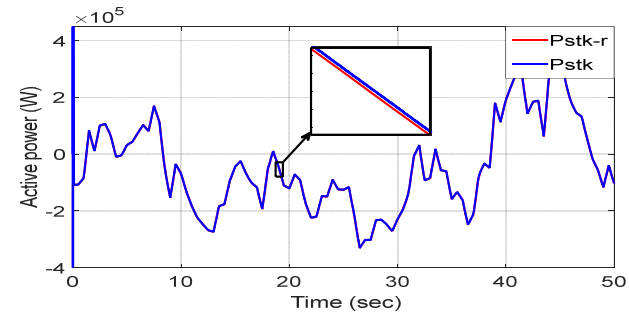

Figure 10. Output active power of the FESS

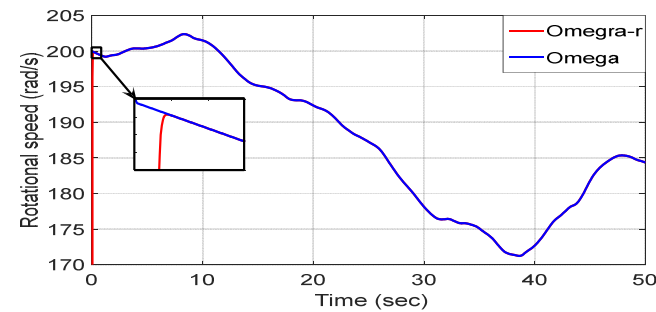

Figure 11. Mechanical speed of the flywheel

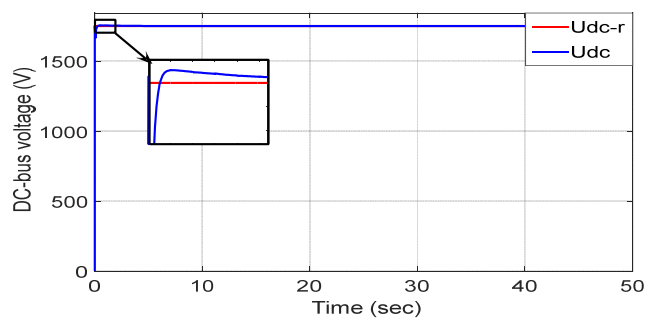

Figure 13. DC-link votage

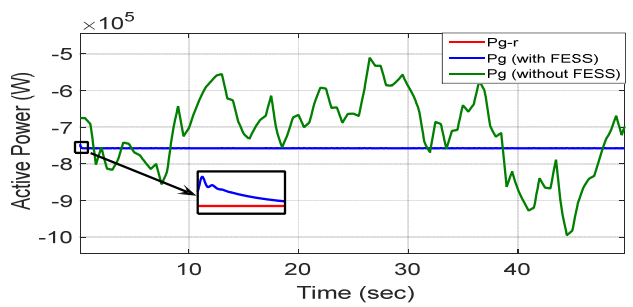

Figure 14. Power injected to the grid

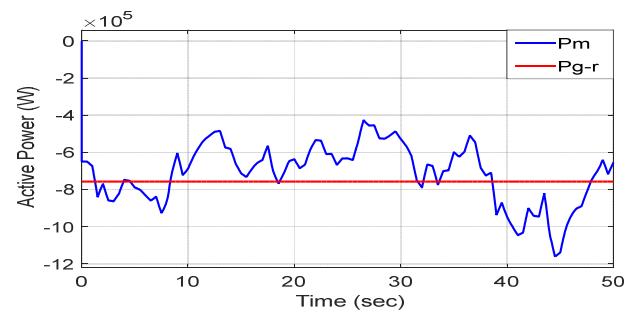

Figure 15. DFIG Active power (robustness test)

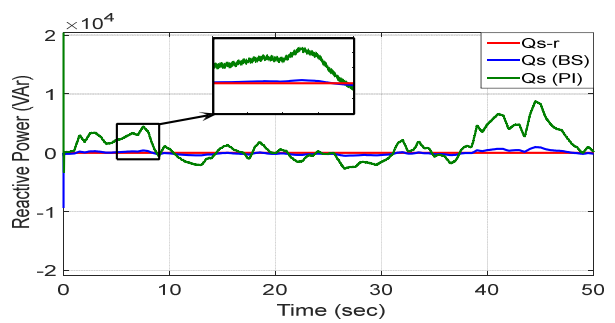

Figure 16. DFIG reactive power (robustness test)

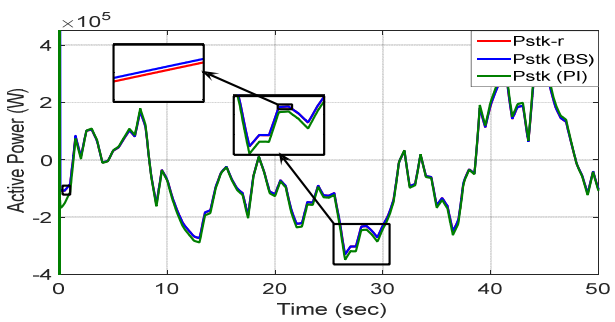

Figure 17. FESS active power (robustness test) 


\section{CONCLUSION}

In this paper, an IM based FESS was associated to a DFIG based wind power plant in order to address the issue of output power fluctuations. A novel robust control algorithm based on field-oriented control schemes and nonlinear backstepping approach was applied, first, for the DFIG control through the DSC in order to ensure MPPT operation and a unity power factor at the PCC. Then, to the NSC for DC-bus voltage and reactive power (exchanged between the NSC and the power system) regulation. And finally, to manage the storage unit operation through the FSC so as to store the energy when available and retrieves it to the power system in the opposite case. Simulation results have shown in one hand, the enhancement introduced to the quality of the power injected with the support of the storage device. On the other hand, they validate the improvement achieved by applying the proposed control algorithms compared to classical controllers under ideal operating condition and in a case where models parametric variation is registered.

\section{ACKNOWLEDGEMENTS}

The encouragement of the "CNRST National Center for Scientific and Technical Research " is acknowledged.

\section{APPENDIX}

Wind Turbine parameters. Rotor blade radius $R=35 \mathrm{~m}$, mechanical gearbox $\mathrm{G}=60$. Moment of inertia $\mathrm{J}=4 \mathrm{M}$ $\mathrm{kg} / \mathrm{m} 2$. Damping coefficient $\mathrm{f}=0.017$ N.m.s $/ \mathrm{rd}$ and the density of air $\rho=1.2 \mathrm{~kg} / \mathrm{m} 3$.

DFIG parameters: Rated Power $1.5 \mathrm{Mw}$, grid voltage line to line $\mathrm{V}_{\mathrm{s}}=690 ; \mathrm{f}_{\mathrm{s}}=50 \mathrm{~Hz}$, number of pole pair $p=2$, stator \& rotor resistances and inductances $R_{s}=12 \mathrm{~m} \Omega, R_{r}=21 \mathrm{~m} \Omega, L_{s}=13.7 \mathrm{mH}, L_{r}=13.6 \mathrm{mH}$, respectively. Mutual Inductance $\mathrm{M}=13.5 \mathrm{mH}$.

FESS (IM) parameters: Rated power $450 \mathrm{kw}$, number of pole pair $\mathrm{p}=2$, stator \& rotor resistances and inductances $\mathrm{R}_{\mathrm{s}}=51 \mathrm{~m} \Omega, \mathrm{R}_{\mathrm{r}}=51 \mathrm{~m} \Omega, \mathrm{L}_{\mathrm{s}}=47.1 \mathrm{mH}, \mathrm{L}_{\mathrm{r}}=40.7 \mathrm{mH}$, respectively. Mutual Inductance $\mathrm{M}=40.1 \mathrm{mH}$, flywheel inertia $J_{v}=729.5 \mathrm{~kg} / \mathrm{m}^{2}$ and the viscous friction coefficient $\mathrm{f}=0.008 \mathrm{~N} . \mathrm{m} . \mathrm{s} / \mathrm{rd}$.

DC-link \& the filter parameters: $\mathrm{R}_{\mathrm{t}}=2 \mathrm{~m} \Omega, \mathrm{L}_{\mathrm{t}}=5 \mathrm{~m} \Omega$, DC link capacitor $C=4400 \mu \mathrm{F}$ and voltage $\mathrm{U}_{\mathrm{dc}}=1750 \mathrm{~V}$.

\section{REFERENCES}

[1] F. Díaz-González, A. Sumper, O. Gomis-Bellmunt, and F. D. Bianchi, "Energy management of flywheel-based energy storage device for wind power smoothing," Appl. Energy, vol. 110, pp. 207-219, 2013.

[2] G. O. Cimuca, C. Saudemont, B. Robyns, and M. M. Radulescu, "Control and performance evaluation of a flywheel energy-storage system associated to a variable-speed wind generator," IEEE Trans. Ind. Electron., vol. 53, no. 4, pp. 1074-1085, 2006.

[3] M. Y. Khamaira, A. M. S. Yunus, and A. Abu-Siada, "Improvement of DFIG-based WECS performance using SMES unit," in Power Engineering Conference (AUPEC), 2013 Australasian Universities, 2013, pp. 1-5.

[4] I. M. Syed, B. Venkatesh, B. Wu, and A. B. Nassif, "Two-layer control scheme for a supercapacitor energy storage system coupled to a Doubly fed induction generator," Electr. Power Syst. Res., vol. 86, pp. 76-83, 2012.

[5] R. Cárdenas, R. Peña, G. M. Asher, J. Clare, and R. Blasco-Giménez, "Control strategies for power smoothing using a flywheel driven by a sensorless vector-controlled induction machine operating in a wide speed range," IEEE Trans. Ind. Electron., vol. 51, no. 3, pp. 603-614, 2004.

[6] X. Luo, J. Wang, M. Dooner, and J. Clarke, "Overview of current development in electrical energy storage technologies and the application potential in power system operation," Appl. Energy, vol. 137, pp. 511-536, 2015.

[7] M. E. Amiryar and K. R. Pullen, "A review of flywheel energy storage system technologies and their applications," Appl. Sci., vol. 7, no. 3, p. 286, 2017.

[8] L. Jerbi, L. Krichen, and A. Ouali, "A fuzzy logic supervisor for active and reactive power control of a variable speed wind energy conversion system associated to a flywheel storage system," Electr. power Syst. Res., vol. 79, no. 6, pp. 919-925, 2009.

[9] M. Nadour, A. Essadki, and T. Nasser, "Comparative Analysis between PI \& Backstepping Control Strategies of DFIG Driven by Wind Turbine," Int. J. Renew. Energy Res., vol. 7, no. 3, pp. 1307-1316, 2017.

[10] S. Mensou, A. Essadki, T. Nasser, and B. B. Idrissi, "An Efficient Nonlinear Backstepping Controller Approach of a Wind Power Generation System Based on a DFIG," Int. J. Renew. Energy Res., vol. 7, no. 4, 2017.

[11] M. Nadour, A. Essadki, M. Fdaili, and T. Nasser, "Advanced Backstepping Control of a Wind Energy Conversion System Using a Doubly-Fed Induction Generator," in 2017 International Renewable and Sustainable Energy Conference (IRSEC), 2017, pp. 1-6.

[12] M. Fdaili, A. Essadki, and T. Nasser, "Comparative Analysis Between Robust SMC \& Conventional PI Controllers Used in WECS Based on DFIG,” Int. J. Renew. Energy Res., vol. 7, no. 4, pp. 2151-2161, 2017.

[13] Ihedrane Yasmine, El Bekkali Chakib, Bossoufi Badre, "Improved Performance of DFIG-generators for Wind Turbines Variable-speed," Int. J. Power Electron. Drive Syst., vol. Vol. 9, no. No. 4, p. 1875 1890.

[14] R. Chakib, M. Cherkaoui, and A. Essadki, "Inertial response used for a short term frequency control for DFIG wind turbine controlled by ADRC," ARPN J. Eng. Appl. Sci., vol. 11, no. 5, 2016. 
[15] S. Ghosh and S. Kamalasadan, "An Integrated Dynamic Modeling and Adaptive Controller Approach for Flywheel Augmented DFIG Based Wind System," IEEE Trans. Power Syst., vol. 32, no. 3, pp. 2161-2171, 2017.

[16] M. Fdaili, A. Essadki, M. Nadour, and T. Nasser, "Comparative Study of MPPT and Pitch Angle Control Strategies for a Wind Energy Conversion System," in 2017 International Renewable and Sustainable Energy Conference (IRSEC), 2017, pp. 1-6.

[17] Moussa Reddak, Abdelouahed Mesbahi, Ayoub Nouaiti, "Design and implementation of nonlinear integral backstepping control strategy for single-phase grid connected VSI," Int. J. Power Electron. Drive Syst., vol. Vol. 10, no. No. 1, p. 19 26.

[18] Abdallah Abden, A. Bouchetta, O. Boughazi, A. Baghdadi, "Double star induction machine using nonlinear integral backstepping control,” Int. J. Power Electron. Drive Syst., vol. Vol. 10, no. No. 1, p. 27 40.

[19] T. Ghennam and E.-M. Berkouk, "Back-to-back three-level converter controlled by a novel space-vector hysteresis current control for wind conversion systems," Electr. Power Syst. Res., vol. 80, no. 4, pp. 444-455, 2010.

[20] G. Lefebvre, X. Lin-Shi, M. Nadri, J.-Y. Gauthier, and A. Hijazi, "Observability measurement and control strategy for induction machine sensorless drive in traction applications," IFAC-PapersOnLine, vol. 50, no. 1, pp. 15773$15779,2017$.

\section{BIOGRAPHIES OF AUTHORS}
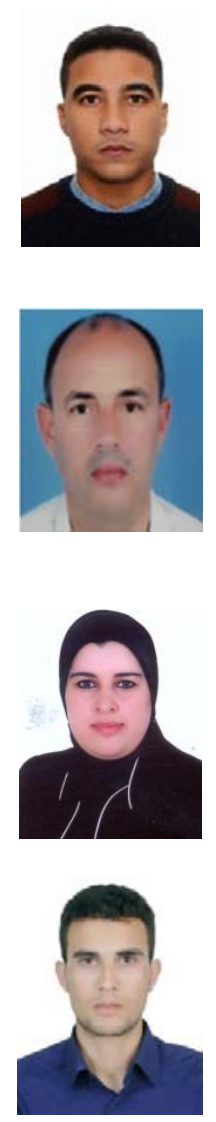

Mohamed NADOUR was born in Casablanca, Morocco, in 1993. He received the M.S degree in electrical engineering in 2016 from Mohammed V University, ENSET Rabat-Morocco. Currently he is working toward the Ph.D. in the Research Centre of Engineering and Health Sciences and Technologies (STIS), since 2016. His research interests are related to renewable energy. His current activities includes strategies of control of a wind-energy conversion system, and energy storage technologies.

Ahmed ESSADKI is currently a Research Professor in the Research Centre of Engineering and Health Sciences and Technologies (STIS). And a professor in the electrical engineering at ENSET, Mohammed V University, Morocco. In 2000, He received his $\mathrm{PhD}$ degree from Mohammadia Engineering School (EMI), (Morocco). From 1990 to 1993, he pursued his Master program at UQTR University, Quebec Canada, respectively, all in electrical engineering. His current research interests include renewable energy, motors drives and power system.

Tamou NASSER is currently an Associate Professor at the communication networks department of National High School for Computer Science and Systems (ENSIAS), Mohammed V University, Morocco, since 2009. She received her PhD degree in 2005 and her research MS degree, in 2000, respectively, all in electrical engineering from Mohammadia Engineering School (EMI), Morocco. Her research interests renewable energy, motor drives, power system, and Smart Grid.

Mohammed Fdaili was born in Khouribga, Morocco, in 1991. He received the M.S degree in Electrical Engineering in 2016 from Mohammed V University, School ENSET, Rabat, Morocco. He is currently working toward the Ph.D. degree in Electrical, since 2016. His research interests are related to renewable energies, particularly in the field of wind turbines. His current activities includes control strategies of wind energy conversion system. 